\title{
Kemampuan Representasi Matematis Ditinjau dari Kemandirian Belajar dengan Model Pembelajaran Berbasis Masalah dan Inkuiri
}

\author{
Iyam Maryati ${ }^{*}$, Fitri Suryaningsih ${ }^{2}$ \\ ${ }^{1,2}$ Institut Pendidikan Indonesia \\ *iyammaryati81@gmail.com
}

\begin{tabular}{|l|l|l|l|}
\hline Received : 12-03-2021 & Revised: 03-11-2021 & Accepted: 05-11-2021 & Published: 21-12-2021 \\
\hline
\end{tabular}

\begin{abstract}
ABSTRAK
Tujuan dari penelitian ini adalah untuk mengetahui perbedaan kemampuan representasi matematis ditinjau dari kemandirian bealjar antara siswa yang mendapatkan model pembelajaran berbasis masalah dan inkuiri. Penelitian ini dilakukan pada siswa kelas X MIA 1, dan X MIA 3 di MAN 2 Garut tahun ajaran 2019/2020. Metode penelitian yang digunakan dalam penelitian ini adalah penelitian kuasi eksperimen. Adapun Teknik pengumpulan data dengan triangulasi data, instrument yang digunakan yaitu soal tes kemampuan representasi matematis dan lembar angket kemandirian siswa. Berdasarkan hasil penelitian, pengolahan data, analisis, dan pengujian hipotesis, maka didapatkan hasil sebagai berikut: (1) Terdapat perbedaan kemampuan representasi matematis antara siswa yang mendapatkan model pembelajaran berbasis masalah dan inkuiri; (2) Tidak terdapat perbedaan representasi matematis ditinjau dari kemandirian belajar antara siswa yang mendapatkan model model pembelajaran berbasis masalah dan inkuiri; (3) Kemandirian belajar siswa terhadap model pembelajaran berbasis masalah berinterpretasi baik; (4) Kemandirian belajar siswa terhadap model pembelajaran inkuiri berinterpretasi baik.
\end{abstract}

Kata Kunci : kemandirian belajar, pembelajaran berbasis masalah, pembelajaran inkuiri, representasi matematis

\section{ABSTRACT}

The purpose of this study was to determine the differences in mathematical representation abilities in terms of self-regulated learning between students who received problem-based and inquirybased learning models. This research was conducted on students of class X MIA 1, and X MIA 3 at MAN 2 Garut in the 2019/2020 school year. The research method used in this research is quasiexperimental research. As for the technique of collecting data with data triangulation, the instruments used are test questions of mathematical representation abilities and student independence questionnaire sheets. Based on the results of research, data processing, analysis, and hypothesis testing, the following results were obtained: (1) There were differences in mathematical representation abilities between students who received problem-based and inquiry-based learning models; (2) there is no difference in mathematical representation in terms of self-regulated learning between students who receive problem-based and inquiry-based learning models; (3) students' self-regulated learning towards problem-based learning models has good interpretation; (4) Students' learning independence towards the inquiry learning model has a good interpretation.

Keywords: mathematical representation, self-regulated learning, problem based learning, inkuiri learning

\section{PENDAHULUAN}

Matematika merupakan pelajaran yang memiliki peranan penting dalam pendidikan. Hal tersebut ditunjukkan dengan dijadikannya matematika sebagai salah satu 
pelajaran wajib pada setiap jenjang pendidikan (Rizkiani \& Septian, 2019). Sesuai dengan pernyataan Depdiknas (2006: 345) yang menyatakan bahwa mata pelajaran matematika perlu diberikan kepada semua siswa mulai dari sekolah dasar sampai perguruan tinggi untuk membekali siswa dengan kemampuan berpikir logis, analitis, sistematis, kritis, dan kreatif serta kemampuan bekerjasama. Sehingga sebagai seorang guru harus mampu membuat siswa mengerti tentang tujuan belajar dan hasil yang akan diperoleh.

Ramziah (2016) mengemukakan bahwa National Council of Teachers of Mathematics menyebutkan proses pembelajaran lebih menekankan pada lima standar proses yaitu pemecahan masalah (problem solving), penalaran dan bukti (reason and proof), komunikasi (communication), koneksi (connections), dan representasi (representation). Berdasarkan lima tujuan pembelajaran yang telah dikemukakan, kemampuan representasi merupakan salah satu tujuan umum dari pembelajaran matematika di sekolah. Kemampuan representasi matematis merupakan aspek yang sangat penting dalam prinsip pembelajaran matematika (Komala \& Sarmini, 2020). Siswa dalam belajar matematika harus disertai dengan pemahaman, hal ini merupakan tujuan dari belajar matematika. Siswa dapat mengembangkan dan memahami konsep matematis lebih dalam, dengan menggunakan representasi yang bermacam-macam.

Programme for International Student Assessment (PISA) adalah studi internasional yang meneliti kemampuan matematika, literasi dan sains setiap tiga tahun sekali dimulai sejak tahun 2001. Survei PISA merupakan program penilaian evaluasi yang dilakukan oleh Organization for Economic Cooperation and Development (OECD) untuk mengevaluasi sistem pendidikan dari 72 negara di seluruh dunia. Survey terakhir PISA dilakukan pada tahun 2015 dengan mengusung tema kompetisi sains. Survei yang dilakukan terhadap siswa berumur 15 tahunan ini meneliti 3 bidang yaitu science, reading, dan mathematics. Pada laporan hasil matematika, Indonesia berada pada rangking ke-63 dari 70 negara, dengan kata lain, Indonesia berada pada urutan ke-8 terbawah. Hal ini bisa dilihat dari kemampuan matematika siswa, dimana 30\% dari siswa Indonesia berada pada level 1 dan 40\% siswa berada di bawah level 1 dari 6 level yang diberikan. Padahal, kemampuan representasi matematis muncul pada level 2 sampai level 6. Hal ini menunjukkan bahwa kemampuan representasi matematis siswa masih rendah.

Penelitian lain yang dilakukan oleh Noto, M.S., dan Hartono, W.D (2016) menunjukkan bahwa kemampuan representasi matematika siswa masih rendah. Hal ini dapat dilihat dari hasil pencapaian siswa pada setiap indikator kemampuan representasi yang diteliti. Data mengungkapkan bahwa pada setiap indikator kemampuan representasi 
matematis siswa dibawah 50\%. Setiap kemampuan dalam matematika memiliki indikator kemampuan, dimana indikator ini merupakan fase seorang siswa disebut memiliki kemampuan itu sendiri. Adapun indikator kemampuan representasi matematis seperti pada Tabel 1.

Tabel 1 Bentuk-Bentuk Indikator Representasi Matematis

\begin{tabular}{|c|c|}
\hline Representasi & Bentuk-Bentuk Indikator \\
\hline $\begin{array}{l}\text { Representasi visual; diagram, tabel } \\
\text { atau grafik, dan gambar }\end{array}$ & $\begin{array}{l}\text { - Menyajikan kembali data atau informasidari } \\
\text { suatu representasi ke representasi diagram, } \\
\text { grafik atau tabel.. } \\
\text { - Menggunakan representasi visual untuk } \\
\text { menyelesaikan masalah. } \\
\text { - Membuat gambar pola-pola geometri.. } \\
\text { - Membuat gambar bangun geometri untuk } \\
\text { memperjelas masalah dan mengfasilitasi } \\
\text { penyelesaiannya. }\end{array}$ \\
\hline Persamaan atau ekspresi matematis & $\begin{array}{l}\text { - } \text { Membuat persamaan atau } \quad \text { ekspresi } \\
\text { matematis dari representasi lain yang } \\
\text { diberikan.. } \\
\text { - } \text { Membuat konjektur dari suatu pola bilangan.. } \\
\text { - } \text { Penyelesaian masalah dari suatu } \\
\text { ekspresi matematis. }\end{array}$ \\
\hline Kata-kata atau teks tertulis & $\begin{array}{l}\text { - Membuat situasi masalah berdasarkan data } \\
\text { - } \text { atau representasi yang diberikan. } \\
\text { representasi. } \\
\text { - Menyusun cerita yang sesuai dengan suatu } \\
\text { representasi yang disajikan. } \\
\text { - Menuliskan langkah-langkah penyelesaian } \\
\text { masalah dengan kata-kata atau teks tertulis . } \\
\text { - Membuat dan menjawab pertanyaan dengan } \\
\text { menggunakan kata-kata atau teks tertulis. }\end{array}$ \\
\hline
\end{tabular}


Pembelajaran matematika di sekolah tidak hanya dimaksudkan untuk mengembangkan ranah kognitif saja, melainkan juga ranah afektif. Permendikbud Nomor 54 tahun 2013 mencakup uraian terhadap pentingnya pengembangan aspek afektif dalam proses pembelajaran pada kompetensi lulusan dalam dimensi sikap (Kemendikbud, 2013). Ranah afektif tersebut adalah kemandirian belajar. Kemandirian belajar memiliki hubungan yang signifikan dengan kemampuan matematis siswa (Kurniasih, Darwan, \& Muchyidin, 2020; Tsany, Septian, \& Komala, 2020). Kemandirian belajar (Self Regulated Learning) adalah salah satu ranah afektif yang menjadi faktor penentu terhadap hasil pembelajaran matematika siswa (Kamal, 2015). Kemandirian belajar merupakan proses dimana individu mengambil inisiatif dalam merencanakan, melaksanakan dan mengevaluasi sistem pembelajarannya (Sundayana, 2016). Menurut Astuti (2010), Belajar mandiri bukanlah belajar individual, akan tetapi belajar yang menuntut kemandirian seorang siswa untuk belajar. Kemandirian memerlukan tanggung jawab, mereka yang mandiri adalah mereka yang bertanggung jawab, berinisiatif, memiliki keberanian, dan sanggup menerima resiko serta mampu menjadi pembelajar bagi dirinya sendiri. Indikatorindikator kemandirian belajar adalah: (1) Adanya hasrat atau keinginan yang kuat untuk belajar, (2) Mampu mengambil keputusan dan inisiatif untuk menghadapi masalah, (3) Tanggungjawab atas apa yang dilakukannya,(4) percaya diri dan melaksanakan tugas-tugas secara mandiri.

Salah satu upaya yang dapat dilakukan guru untuk meningkatkan kemampuan representasi belajar dan kemandirian belajar siswa dalam proses pembelajaran matematika dan dapat meningkatkan mutu pendidikan dikatakan oleh Gravemeijer (Farhan Dan Retnawati, 2016) bahwa agar efektif contoh riil perlu lebih banyak dihubungkan dengan pengalaman actual murid. Selain itu menyebutkan pula bahwa model yang diusulkan adalah guru mulai dengan sebuah contoh atau situasi yang realistis, mengubahnya menjadi suatu model matematika, mengarahkannya ke solusi matematika yang kemudian diinterpretasikan kembali sebagai sebuah solusi yang realistik (Rohmah, Septian, \& Inayah, 2020). Strategi semacam ini jelas akan berguna dalam mengkaitkan pengetahuan dan aplikasi matematika dan dunia riil.

Kemampuan Representasi matematis biasanya dikaitkan dengan kemampuan pemahaman matematika dengan menggunakan masalah yang riil membutuhkan suatu pembelajaran yang benar-benar merancang suatu lingkungan belajar dengan permasalahan yang riil atau nyata dengan aktivitas siswa (Septian, Darhim, \& Prabawanto, 2020; Wijayanti \& Amin, 2019) . Dalam hal ini Pembelajaran Berbasis Masalah dan 
Pembelajaran Inkuiri yang merupakan Pembelajaran Berbasis Masalah akan mengantarkan siswa pada situasi masalah yang riil. Masalah-masalah yang riil sangat dibutuhkan dalam proses pembelajaran untuk meningkatkan kemampuan siswa dalam pembelajaran matematika yakni kemampuan siswa dalam bernalar, berpikir logis, sampai pada kemampuan siswa berpikir tingkat tinggi. Pembelajaran Berbasis Masalah pula akan memungkinkan siswa untuk menemukan pembelajaran yang bermakna, siswa akan terlatih untuk memecahkan masalah-masalah riil yang sering muncul serta siswa akan lebih aktif (Farhan \& Retnawati, 2016)

Menurut (Lidnillah, 2013) PEMBELAJARAN BERBASIS MASALAH adalah suatu model pembelajaran yang menggunakan masalah dunia nyata sebagai suatu konteks bagi siswa untuk belajar tentang cara berpikir kritis, dan keterampilan pemecahan masalah, serta untuk memperoleh pengetahuan dan konsep yang esensial dari materi pelajaran. Model ini menyajikan tugas-tugas dalam bentuk masalah dan mengakibatkan siswa berusaha untuk mencari solusinya dengan berbagai ide dan representasi yang sesuai sehingga kemampuan berpikir siswa dimaksimalkan melalui proses pemecahan masalah. Pada prosesnya, model PEMBELAJARAN BERBASIS MASALAH merupakan model pembelajaran yang melibatkan siswa secara aktif untuk menggunakan keterampilan dan konsep yang telah dimilikinya dalam menyelesaikan masalah. Kemampuan representasi matematis pada model PEMBELAJARAN BERBASIS MASALAH bukan merupakan tujuan utama melainkan sebagai kebutuhan untuk meningkatkan kemampuan berpikir. (Maryati, 2016) Karakteristik dari Pembelajaran Berbasis Masalah, yaitu (a) belajar dimulai dengan satu permasalahan, (b) memastikan bahwa masalah tersebut berhubungan dengan dunia nyata murid, (c) mengorganisasikan pelajaran yang berkaitan dengan masalah tersebut dan bukan terkait disiplin ilmu tertentu, (d) memberikan tanggung jawab yang besar kepada murid dalam membentuk dan menjalankan secara langsung proses belajar mereka sendiri, (e) menggunakan kelompok kecil, serta (f) menuntun murid untuk mendemonstrasikan yang telah mereka pelajari dalam bentuk produk atau kinerja.

Sedangkan menurut (Purwasih, 2015) Pembelajaran Pembelajaran Inkuiri (PEMBELAJARAN INKUIRI) merupakan pembelajaran kontruktivisme yang melibatkan siswa secara aktif di dalam pembelajaran, memberikan kesempatan kepada siswa untuk mengumpulkan dan menganalisis informasi, mengeksplorasi pemikiran dan penalarannya sehingga siswa memperoleh pemahaman yang mendalam mengenai materi pembelajaran yang sedang dipelajari. Siswa aktif dalam mengumpulkan berbagai sumber informasi dan mengkonstruksi pengetahuan mereka sendiri melalui pengalaman. memberikan kriteria 
yang sedikit berbeda untuk membimbing pemilihan masalah dalam Inquiry bahwa masalah yang diajukan adalah: (1) kaya akan konseptual yang menyediakan peluang untuk melakukan penyelidikan yang bermakna (yang akan) menghasilkan pemahaman nilai yang abadi, (2) bersifat fleksibel yang berhubungan dengan isu-isu atau masalah yang sifatnya membangun, (3) relevan dengan kehidupan anak (siswa) sehingga keduanya dapat diakses dan menarik.

\section{METODE PENELITIAN}

Metode yang digunakan oleh peneliti dalam penelitian ini adalah metode kuasi eksperimen. Adapun desain penelitiannya adalah sebagai berikut menurut Ruseffendi $(2010,52)$.

$\begin{array}{ccc}\mathrm{O} & \mathrm{X}_{1} & \mathrm{O} \\ \mathrm{O} & \mathrm{X}_{2} & \mathrm{O}\end{array}$

Keterangan:

$\mathrm{O}=$ Tes awal (pretest) dan tes akhir (posttest).

$\mathrm{X}_{1}=$ Pembelajaran menggunakan model Pembelajaran Berbasis Masalah

$\mathrm{X}_{2}=$ Pembelajaran menggunakan model pembelajaran inkuiri

Penelitian ini dilaksanakan di MAN 2 Garut. Kegiatan penelitian dilakukan pada semester ganjil Tahun Pelajaran 2019/2020. Penetapan jadwal penelitian disesuaikan dengan jadwal yang ditetapkan oleh pihak sekolah yaitu tanggal 30 Oktober s/d 21 November 2019. Adapun materi pelajaran yang dipilih dalam penelitian ini adalah Pertidaksamaan Kuadrat yang merupakan materi pada silabus kelas $\mathrm{X}$ yang sedang dipelajari pada semester tersebut.

Populasi dalam penelitian ini adalah seluruh kelas X MIA MAN 02 Garut tahun ajaran 2019/2020. Sampel dalam penelitian ini dilakukan secara purposive sampling sebanyak 2 kelas eksperimen, yaitu kelas X MIA 1 sebagai kelas eksperimen 1 (Pembelajaran Berbasis Masalah) dan kelas X MIA 3 sebagai kelas eksperimen 2 (Pembelajaran Inkuiri).

Analisis data dilakukan dengan menguji normalitas kedua kelompok data terlebih dahulu bertujuan untuk memberikan gambaran terhadap data yang telah dikumpulkan dari hasil penelitian. Kemudian dilanjutkan dengan uji homogenitas dan uji t'. Hal ini dimaksudkan untuk mencari kesimpulan dan menguji hipotesis. Data yang dianalisis diperoleh dari hasil Posttest dan mengisi lembaran angket kemandirian belajar. 


\section{HASIL DAN PEMBAHASAN}

Data yang diperoleh dalam penelitian ini adalah data kemampuan representasi matematis dan data angket kemandirian belajar. Berikut disajikan deskripsi data hasil Posttest dan Gain Ternormalisasi.

Tabel 2 Deskripsi Data Hasil Posttest Dan Gain Ternormalisasi

\begin{tabular}{|c|c|c|c|c|}
\hline \multirow[t]{2}{*}{ Ket } & \multicolumn{2}{|c|}{$\begin{array}{c}\text { Pembelajaran } \\
\text { Berbasis Masalah }\end{array}$} & \multicolumn{2}{|c|}{$\begin{array}{l}\text { Pembelajaran } \\
\text { Inkuiri }\end{array}$} \\
\hline & Posttest & $\begin{array}{c}\text { Gain } \\
\text { Ternormalisasi }\end{array}$ & Posttest & $\begin{array}{c}\text { Gain } \\
\text { Ternormalisasi }\end{array}$ \\
\hline $\mathrm{n}$ & \multicolumn{2}{|c|}{32} & \multicolumn{2}{|c|}{28} \\
\hline xmaks & 15 & 0,88 & 12 & 0,69 \\
\hline $\mathrm{x}_{\min }$ & 4 & 0 & 5 & 0,1 \\
\hline $\bar{x}$ & 9,97 & 0,49 & 8,43 & 0,33 \\
\hline $\mathrm{s}$ & 2,61 & 0,18 & 1,69 & 0,14 \\
\hline
\end{tabular}

Dari Tabel 2 diatas terlihat bahwa rata-rata kelas pembelajaran berbasis masalah untuk data hasil posttest dan gain ternormalisasi lebih besar dari pada kelas pembelajaran inkuiri, terlihat bahwa terdapat perbedaan kemampuan representasi dari kedua kelas eksperimen tersebut.

Berdasarkan hasil Posttest diperoleh rata-rata utuk kelas pembelajaran berbasis masalah dan pembelajaran inkuiri berturut-turut yaitu sebesar 9,97 dan 8,43. Kemudian data tersebut diuji normalitasnya dengan menggunakan Uji Lilliefors, dengan taraf signifikan 5\% menunjukan bahwa kedua kelompok berdistribusi normal. Sehingga dilanjutkan dengan uji homogenitas dan dat tersebut menunjukkan bahwa kedua kelompok tidak homogen maka dilanjutkan dengan uji t' dengan hasil menggunakan uji satu pihak dan taraf signifikan 0,05 diperoleh $\mathrm{t}^{\prime}=2,74$ dan $\mathrm{t}_{\text {hitung }}=2,04$. Karena berada pada daerah penerimaan Ho, sehingga dapat disimpulkan bahwa terdapat perbedaan kemampuan representasi matematis yang signifikan antara siswa yang mendapatkan model pembelajaran berbasis masalah dan pembelajaran inkuiri.

Sama halnya dengan pengujian yang dilakukan untuk perbedaan kemampuan representasi, dalam penelitian ini juga merumuskan perbedaan antara kemampuan representasi matematis ditinjau dari kemandirian belajar. Maka didapatkan data pengelompokkan kemandirian belajar dengan langkah menggabungkan kedua kelompok tersebut menjadi 60 siswa dan dimasukkan kedalam 3 kategori yaitu tinggi, sedang dan 
rendah.dengan menggunakan standar deviasi (Arikunto, 2009) menentukkan kedudukannya adalah:

Tabel 3 Kriteria Penggelompokkan Kemandirian Belajar

\begin{tabular}{cc}
\hline Kriteria & Kategori \\
\hline SRL $\geq 74,55$ & Tinggi \\
$56,75<\mathrm{SRL}<74,55$ & Sedang \\
$\mathrm{SRL} \leq 56,75$ & Rendah \\
\hline
\end{tabular}

Sehingga diperoleh rekapitulasi kelompok untuk kedua kelompok tersebut adalah:

Tabel 4 Rekapitulasi Pengelompokkan Kemandirian Belajar

\begin{tabular}{ccc}
\hline Kemandirian Belajar & Frekuensi & Persentase $(\%)$ \\
\hline Tinggi & 13 & 21,67 \\
Sedang & 29 & 48,33 \\
Rendah & 18 & 30 \\
\hline
\end{tabular}

Berdasarkan hasil Posttest diperoleh rata-rata utuk kelompok tinggi, sedang dan rendah berturut-turut yaitu sebesar 9,15, 8,79 dan 10,06. Kemudian data tersebut diuji normalitasnya dengan menggunakan Uji Lilliefors, dengan taraf signifikan 5\% menunjukan bahwa ketiga kelompok berdistribusi normal. Sehingga dilanjutkan dengan uji homogenitas dan data tersebut menunjukkan bahwa ketiga kelompok homogen maka dilanjutkan dengan uji ANOVA dengan hasil menggunakan uji satu pihak dan taraf signifikan 0,05 diperoleh Fhitung=1,67 dan Ftabel=3,16. Karena $F_{\text {hitung }}<F_{\text {tabel }}$ maka Ho diterima. Sehingga dapat disimpulkan bahwa tidak terdapat perbedaan kemampuan representasi matematis ditinjau dari kemandirian belajar yang signifikan antara siswa yang mendapatkan model pembelajaran Pembelajaran Berbasis Masalahdan Pembelajaran Inkuiri.

Adapun interpretasi kemandirian belajar dengan menggunakan interpretasi skala Likert yang menunjukkan persentase kemandirian belajar siswa tiap individu pada kelas Pembelajaran Berbasis Masalahsebesar 84,375 \% termasuk kategori baik, dan pada kelas Pembelajaran Inkuiri 85,71\% juga termasuk kategori baik.

Adapun faktor mempengaruhi terjadinya perbedaan kemampuan representasi antara siswa yang mendapatkan model pembelajaran berbasis masalah dengan pembelajaran inkuiri, diantaranya adalah dalam proses pembelajarannya itu sendiri siswa pembelajaran berbasis masalah dituntut untuk berusaha mencari jawaban dalam menyelesaikan 
masalahnya, lalu bertanya kepada guru untuk meminta dibimbing saat mengalami kesulitan dalam menyelesaikan masalah yang telah diberikan. sedangkan dalam kelas pembelajaran inkuiri siswa dituntut untuk menyelesaikan masalah secara mandiri dengan mencari informasi yang lebih terlebih dahulu sehingga di saat siswa mencari informasi sebagian siswa menemukan informasi yang kurang tepat. Hal ini diperkuat dengan hasil penelitian sebelumnya yang menyatakan bahwa Pembelajaran Berbasis Masalahlebih efektif dibandingkan dengan Pembelajaran Inkuiri ditinjau dari aspek prestasi belajar, kemampuan representasi matematis, dan motivasi belajar siswa (Yuda \& Lestari, 2014).

Selanjutnya dikemukakan dalam penelitian yang dilakukan oleh Murni (2012) bahwa tidak terdapat korelasi antara kemampuan representasi matematis dan kemandirian belajar siswa yang memperoleh model pembelajaran Pembelajaran Berbasis Masalah berbantuan Software Geogebra. Serta menurut Amalia dan Isnani (2019) mengungkapkan bahwa peningkatan representasi matematis siswa yang menerapkan model pembelajaran Pembelajaran Berbasis Masalah lebih baik daripada peningkatan kemampuan representasi matematis siswa yang mendapat pembelajaran konvensional dan tidak terdapat interaksi antara model pembelajaran dan pengelompokan siswa terhadap peningkatan kemampuan representasi matematis.

Dan menurut Rahmi (2016) menyatakan bahwa siswa yang berkemampuan tinggi dan sedang memenuhi ketiga indikator kemampuan representasi matematis yaitu menuliskan langkah-langkah penyelesaian masalah matematika dengan kata-kata, menyajikan data atau informasi dari suatu masalah ke representasi gambar, diagram, grafik atau tabel, serta menyelesaikan masalah yang melibatkan ekspresi matematis. Siswa berkemampuan rendah memenuhi dua indikator kemampuan representasi matematis yaitu menuliskan langkah-langkah penyelesaian masalah matematika dengan kata-kata dan menyelesaikan masalah yang melibatkan ekspresi matematis.

\section{KESIMPULAN}

Berdasarkan hasil analisis dan pembahasan secara keseluruhan terhadap data penelitian mengenai Perbedaan Kemampuan Representasi Matematis ditinjau dari kemandirian belajar antara Siswa yang Mendapatkan Model Pembelajaran Berbasis Masalah dengan Pembelajaran Inkuiri, maka sesuai dengan rumusan masalah peneliti memperoleh kesimpulan yaitu 1) Perbedaan kemampuan representasi matematis antara siswa yang mendapatkan model Pembelajaran Berbasis Masalah dengan Pembelajaran Inkuiri yang ditinjau dari: a) keseluruhan didapatkan bahwa: Terdapat Perbedaan 
kemampuan representasi matematis yang signifikan antara siswa yang mendapatkan model Pembelajaran Berbasis Masalah dengan Pembelajaran Inkuiri; b) kemandirian belajar siswa, didapatkan bahwa: Tidak terdapat perbedaan representasi matematis yang signifikan ditinjau dari kemandirian belajar antara siswa yang mendapatkan model Pembelajaran Berbasis Masalah dengan Pembelajaran Inkuiri; 2) Kemandirian belajar siswa terhadap model Pembelajaran Berbasis Masalah berinterpretasi baik; 3) Kemandirian belajar siswa terhadap model Pembelajaran Inkuiri berinterpretasi baik.

\section{REFERENSI}

Amalia, S. R., \& Isnani, I. (2019). Representasi matematis dalam pembelajaran dengan model problem-based learning berbasis etnomatematika ditinjau dari tipe kepribadian. Jurnal Elemen. https://doi.org/10.29408/jel.v5i2.1325

Astuti. (2010). Kemandirian belajar matematika siswa SMP/ MTs di Kecamatan Prembun. Jurnal FkIP, Universitas Muhammadiyah Purworejo.

Farhan Dan Retnawati. (2016). Keefektifan PBL dan IBL ditinjau dari prestasi belajar, kemampuan representasi matematis, dan motivasi belajar. Jurnal Pendidikan Matematika UNY.

Kamal, S. (2015). Implementasi pendekatan scientific untuk meningkatkan kemandirian belajar matematika. Math Didactic: Jurnal Pendidikan Matematika. https://doi.org/10.33654/math.v1i1.95

Kemendikbud. (2013). Peraturan Menteri Pendidikan Dan Kebudayaan Republik Indonesia Nomor 54 Tahun 2013 Tentang Standar Kompetensi Lulusan Pendidikan Dasar Dan Menengah (Salinan). Jakarta: Kementerian Pendidikan dan Kebudayaan.

Komala, E., \& Sarmini, S. (2020). Kemampuan representasi simbolik matematik siswa smp menggunakan blended learning. Prisma, 9(2), 204. https://doi.org/10.35194/jp.v9i2.1078

Kurniasih, S., Darwan, D., \& Muchyidin, A. (2020). Menumbuhkan kemandirian belajar matematika siswa melalui mobile learning berbasis android. Jurnal Edukasi Matematika Dan Sains. https://doi.org/10.25273/jems.v8i2.7041

Lidnillah. (2013). Pembelajaran Berbasis Masalah (Problem Based Learning). [Online].http://File:UPI,Edu/Direkt Ori/KD,Tasikmalaya/Dindin_abdul_muizLidnillah. Diakses Pada Tanggal 10 Januari 2020.

Maryati, I. (2016). Upaya meningkatkan kemampuan pemecahan masalah matematik siswa sekolah menengah pertama melalui pembelajaran kontekstual. 7(1), 1-9.

Murni, A. (2012). Peningkatan kemampuan representasi matematis siswa SMP melalui pembelajaran metakognitif dan pembelajaran metakognitif berbasis softskill. Pendidikan.

Noto, M. S., Hartono, W. D, \& S. (2016). Analysis of students mathematical representation and connection on analytical geometry subject. Infinity Journal, 5(2), 99-108.

Purwasih, R. (2015). Peningkatan Kemampuan Pemahaman Matematis Dan Self Confidence Siswa MTs Di Kota Cimahi Melalui Model Pembelajaran Inkuiri Terbimbing. Jurnal Ilmiah STKIP Siliwangi Bandung.

Rahmi, M. (2016). Peningkatan kemampuan representasi matematis melalui model problem based learning pada siswa SMP/MTs. Program Pendidikan Matematika, Universitas Negeri Ar-Raniry, Banda Aceh.

Ramziah. (2016). Peningkatan kemampuan representasi matematis siswa kelas X2 SMAN 
1 Gedung Meneng menggunakan bahan ajar matriks berbasis pendekatan saintifik. Jurnal Pendidikan Matematika STKIP Garut.Http://E-Mosharafa.Org/ Diakses Pada 26 Februari 2019.

Rizkiani, A., \& Septian, A. (2019). Kemampuan metakognitif siswa SMP dalam pembelajaran matematika dengan menggunakan pendekatan realistic mathematics education ( RME ). UNION: Jurnal Pendidikan Matematika, 7(2), 275-284.

Rohmah, W. N., Septian, A., \& Inayah, S. (2020). Analisis kemampuan penalaran matematis materi bangun ruang ditinjau gaya kognitif siswa menengah pertama. PRISMA. https://doi.org/10.35194/jp.v9i2.1043

Septian, A., Darhim, \& Prabawanto, S. (2020). Geogebra in integral areas to improve mathematical representation ability. Journal of Physics: Conference Series, 1613(1), 012035. https://doi.org/10.1088/1742-6596/1613/1/012035

Sundayana. (2016). Kaitan antara gaya belajar, kemandirian belajar, dan kemampuan pemecahan masalah siswa SMP dalam pelajaran matematika. Jurnal Mosharafa, 5(2)

Tsany, U. N., Septian, A., \& Komala, E. (2020). The ability of understanding mathematical concept and self-regulated learning using macromedia flash professional 8. Journal of Physics: Conference Series, 1657(1), 012074. https://doi.org/10.1088/17426596/1657/1/012074

Wijayanti, W., \& Amin, S. M. (2019). Representasi matematis siswa dalam memecahkan masalah matematika kontekstual ditinjau dari kemampuan matematika. MATHEdunesa. https://doi.org/10.26740/mathedunesa.v8n3.p492-499

Yuda, M. R., \& Lestari, K. E. (2014). Meningkatkan kemampuan representasi beragam matematis siwa melalui pembelajaran berbasis masalah terbuka. Jurnal Ilmiah Solusi Vol.1. 